口絵 1 : 東日本大震災の津波被害と津波堆積物の採取

\title{
Pictorial 1 : Tsunami Disaster Associated with the Great East Japan Earthquake and Sampling Tsunami Deposits
}

東日本大震災による津波被害地域の様子と試料採取 (2011 年 4 月から 7 月撮影).

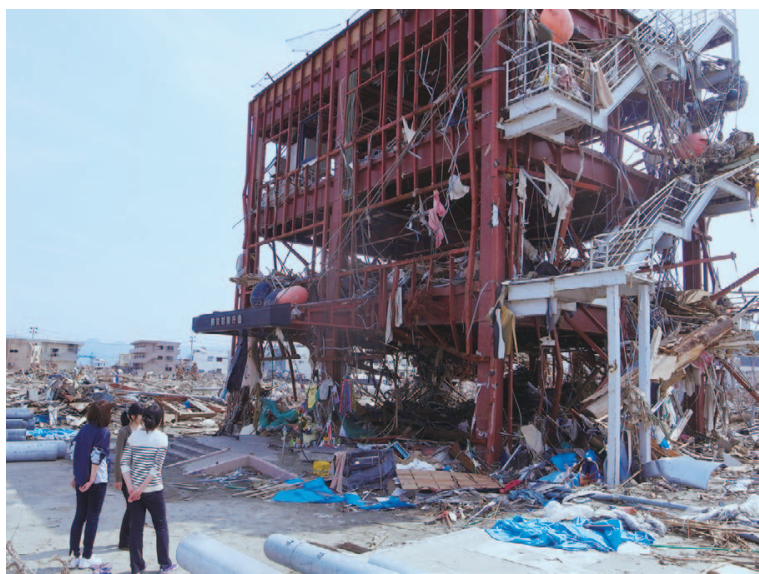

図 1 南三陸町志津川の防災対策庁舎. 津波はこの建物の屋 上に達し多くの人が犠牲となった.この時点 (2011. 6.4) では充分に整理されておらず，震災後そのままの状態 であった，東日本大震災の震災遺構として保存するか についてはいまだ議論が続いている（2014 年末現在）.

Fig. 1 Minamisanriku town's Crisis Management Department (Shizugawa). The tsunami killed a large number of people. Photo was taken on $4^{\text {th }}$ June 2011 before the cleanup began. This building is a candidate for a disaster memorial building, but the final decision has yet to be made (2014 year-end).

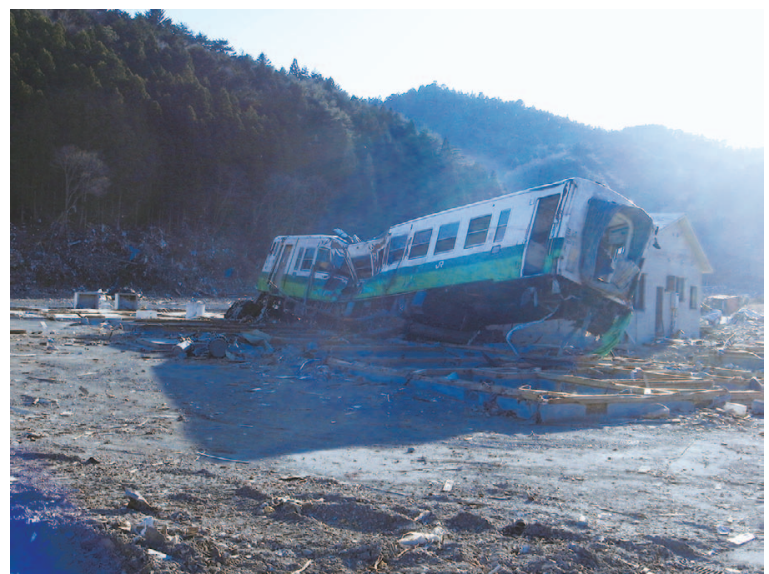

図 2 女川駅に残された列車. 約 $200 \mathrm{~m}$ 山側に移動してい る (2011. 4.16 撮影)。石巻から女川に通じる鉄路は いまだ開通していない（2014 年末現在）。

Fig. 2 Damaged train, which was carried ca. $200 \mathrm{~m}$ along the mountain side from JR Onagawa station. Photo was taken on $16^{\text {th }}$ April, 2011. The railway from Ishinomaki to Onagawa has still not reopened (2014 year-end).
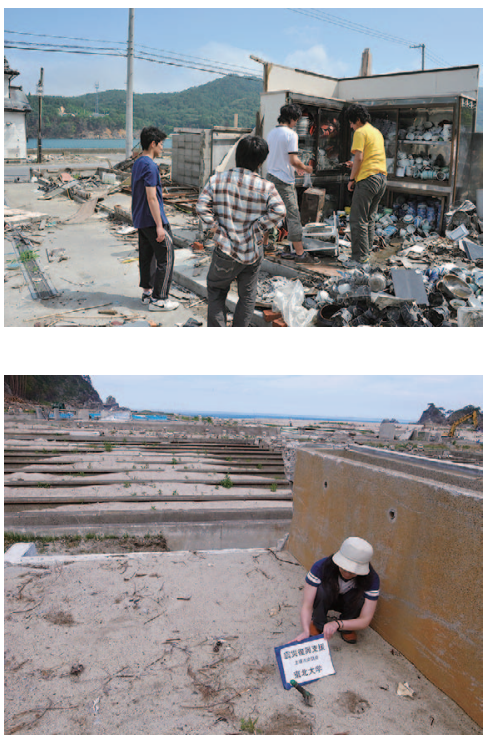

図 4 建物が流された後の土台に貯 まった津波堆積物。これらはま だ復旧工事の影響を受けていな い(田野畑 2011.7.6 撮影).

Fig. 4 Tsunami deposits in a building basement. Sediments were not contaminated (Photo was taken at Tanohata, $6^{\text {th }}$ July, 2011).

図 3 雄勝港に近接する料理屋の食器棚から津波堆積物を採取する東北大学の 1 年 生.このような場所から津波堆積物を採取することにより，復旧工事などに污 染されていない津波堆積物を得ることができた。建物自体は津波で流されてい る(2011.6. 4 撮影).

Fig. 3 Fresh-year students of Tohoku University collect tsunami deposits from a sideboard of a Japanese-style restaurant beside Ogatsu port. It was possible to collect uncontaminated tsunami deposits. The main building was destroyed by the tsunami (Photo was taken on $4^{\text {th }}$ June, 2011).
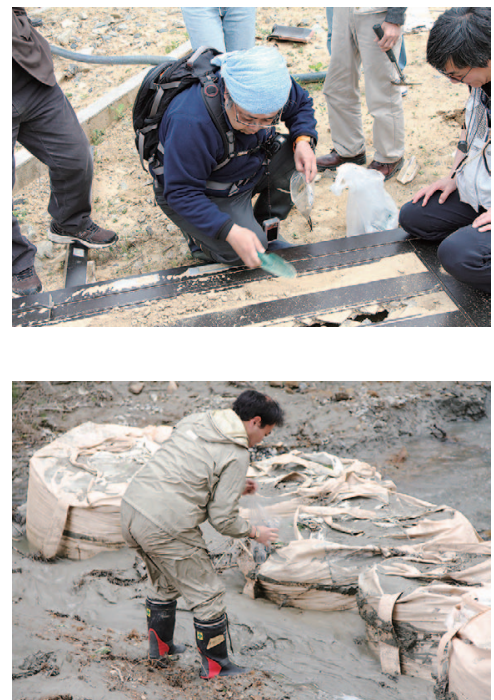

図 5 気仙沼市本吉地区の大谷鉱山下流域 でのサンプリング風景. 高濃度のヒ 素が検出された（図 7 の NH4 地点） (2011.6. 1 撮影)

Fig. 5 Downstream from Oya Mine, Motoyoshi, Kesennuma City. High concentrations of Arsenic were observed in tsunami deposits (NH4 point in Fig. 7) (Photo was taken on $1^{\text {st }}$ June, 2011).

図 6 気仙沼市本吉地区の大谷鉱山下流域 でのサンプリング風景.この地点は 上流のダムから流れ落ちた鉱滓から なる。ここからはきわめて高いヒ素 が検出された (図 7 の NH1 地点).

Fig. 6 Downstream from Oya Mine, Motoyoshi, Kesennuma City. Slag from the tailing dam of Oya Mine. Extremely high concentrations of Arsenic were analyzed (NH1 point in Fig. 7) (Photo was taken on $1^{\text {st }}$ June, 2011). 
口絵 1 (つづき)：東日本大震災の津波被害と津波堆積物の採取

Pictorial 1 : Tsunami Disaster Associated with the Great East Japan Earthquake and Sampling Tsunami Deposits

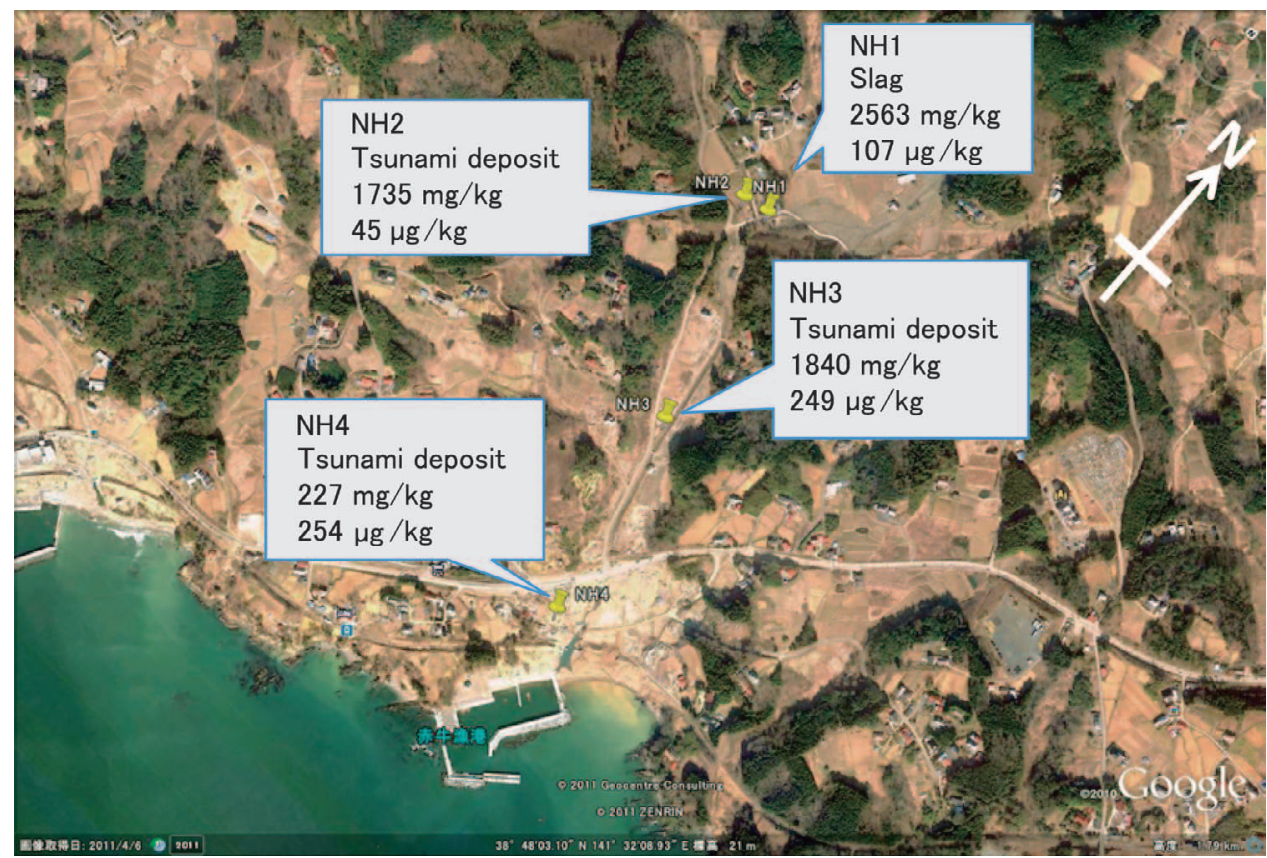

図 7 気仙沼市本吉地区の大谷鉱山下流域. 上流の尾鉱ダムが決壊し, 鉱滓が下流域に流れるとと もに，海からは高濃度のヒ素を含む津波堆積物が遡上した．各地点の分析值の上段が含有量, 下段が水溶出量を示す．水溶出量の環境基準は $10 \mathrm{mg} / \mathrm{kg}$ なので，この数值は環境基準を大き く上回っていた.

Fig. 7 Downstream from Oya Mine, Motoyoshi, Kesennuma City. Here, the tailing dam was destroyed by the earthquake and slag flowed downstream. Tsunami deposits containing high concentrations of Arsenic were carried up from the ocean. Analytical values are shown in the squares: up is concentration of As and down is water extraction of As. Environmental standard for water extraction of As is $10 \mathrm{mg} / \mathrm{kg}$. The values here are significantly higher than the environmental standard.

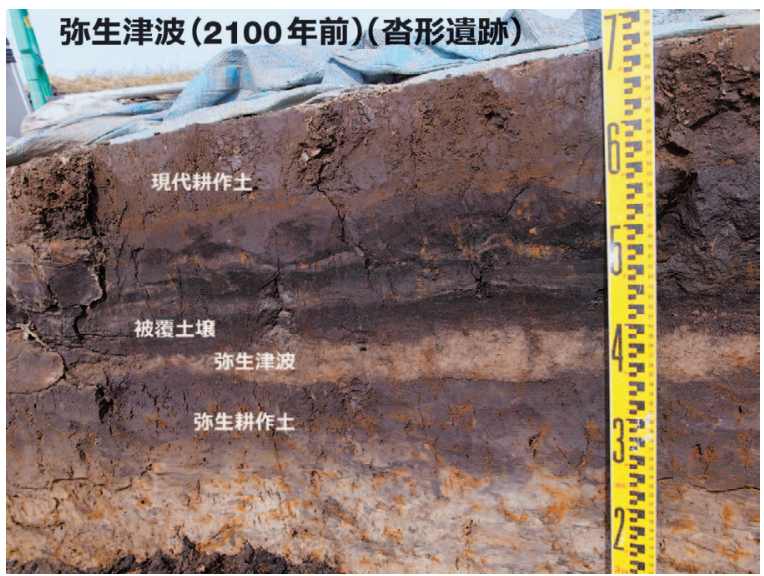

図 8 仙台市若林区荒井の弥生時代の遺跡（沓形遺跡）に認 められる津波堆積物 (2100 年前の津波堆積物と考え られる)。

Fig. 8 Paleotsunami deposit observed at Kutsukata excavation (2100 B.P.), Arai, Wakabayashi Ward, Sendai City.

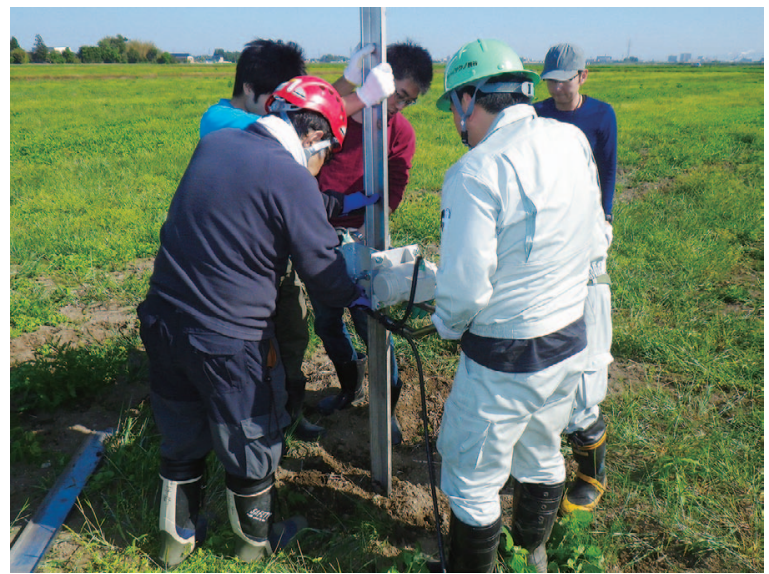

図 9 仙台市平野でのジオスラーサーを用いた歴史津波堆積 物の採取.

Fig. 9 Sampling paleotsunami deposits using Geo-Slicer on the Sendai Plain.

Figs. 1, 2, 3, 4, and 8 are from N.T., and Figs. 5 and 6 are from RISTEX. All figure captions are from N. Tsuchiya. 